\title{
Powerful Peace: A Navy SEAL's Lesson on Peace from a Lifetime at War. By J. Robert Du Bois. New York Counter Insurgency, N.Y.: Morgan James Publishing, 2012.
}

Don Sine

American Military University

Follow this and additional works at: https://digitalcommons.usf.edu/jss

pp. 119-122

\section{Recommended Citation}

Sine, Don. "Powerful Peace: A Navy SEAL's Lesson on Peace from a Lifetime at War. By J. Robert Du Bois. New York Counter Insurgency, N.Y.: Morgan James Publishing, 2012.." Journal of Strategic Security 5, no. 4 (2012) : 119-122.

DOI: http://dx.doi.org/10.5038/1944-0472.5.4.8

Available at: https://digitalcommons.usf.edu/jss/vol5/iss4/2

This Book Review is brought to you for free and open access by the Open Access Journals at Digital Commons @ University of South Florida. It has been accepted for inclusion in Journal of Strategic Security by an authorized editor of Digital Commons @ University of South Florida. For more information, please contact digitalcommons@usf.edu. 
Powerful Peace: A Navy SEAL's Lesson on Peace from a Lifetime at War. By J. Robert Du Bois. New York Counter Insurgency, N.Y.: Morgan James Publishing, 2012. 


\section{Book Reviews}

\begin{abstract}
Powerful Peace: A Navy SEAL's Lessons on Peace from a Lifetime at War. By J. Robert Du Bois. New York Counter Insurgency, NY: Morgan James Publishing, 2012. ISBN 978-161448-188-1. Autobiography. List of Terms and Abbreviations. Resources. Pp. 206. \$24.95.
\end{abstract}

Author J. Robert DuBois knows of what he speaks. In this highly credible, if somewhat audacious monograph, he extolls the virtues of a middle path for maximizing peace through compassionate, balanced power and blending the strengths of timely, pragmatic humanism with the judicious use of raw force. A seasoned and highly accomplished multilingual U.S. Navy SEAL with professional "on-the-ground" combat leadership experience in over thirty nations, Robert DuBois won his sterling national security and peacemaker credentials the hard way.

Robert DuBois is not just any author. He has lived his successful career amidst that of which he presumes to speak. More importantly, Robert DuBois has a message here that is intended for and deserves careful scrutiny of national security policymakers, politicians, military leaders and peace proponents alike. DuBois is not suggesting avoidance of war at all costs, but rather the SMART way to dilute conflict, synergize crosscultural interests and promote collaboration. In publishing this book and its amazingly common sense thesis, Robert DuBois reveals the breadth and depth of his extensive national security expertise.

Robert DuBois retired from his military career in 2006, returning to Iraq and Afghanistan to support and advise military commanders and units involved in complex threat situations. Using his own "Think Like An Adversary" workshops, DuBois trained both U.S. and allied units in threat and risk minimizing techniques, which proved quite successful in the field. Later, the author applied the same concepts in commercial contexts for numerous Fortune 500 corporations and met with similar success in reducing costly and debilitating friction.

Known as a "Smart Power" authority from his advisory support of British and Iraqi forces, Robert DuBois has advised the National Counterterror-

Journal of Strategic Security

(c) 2012 ISSN: 1944-0464 eISSN: 1944-0472 
ism Center, served on the Deputy Secretary of Defense's Senior Integration Group (SIG), led the DoD's Red Team operations and currently is Chairman for the Homeland Security Foundation of America's National Security Subcommittee. In addition to being Chief Security Officer for the AllHumanity Group, Robert DuBois is the founder and CEO of VoDoBo Consulting in Washington, DC where he lives with his family. This background is the foundation upon which Robert DuBois's book, Powerful Peace is based.

The reader will find Powerful Peace well written with crisp, invigorating prose interspersed with frequent and adroitly positioned provocative quotations from diverse and august sources that both focus and illuminate the thesis of this insightful book. Robert DuBois's thesis is professionally provocative, realistically human and perhaps somewhat of a reach for a world power like the United States which continues to marginalize the value of HUMINT. The question arises how Applied Smart Power and Balanced Peacemaking can best be made relevant in this virtual electronic and nuclear age?

DuBois readily credits Professor Nye's PublicAffairs, 2011 article The Future of Power, as the kernel for his more humanized concept of Applied Smart Power which is the judicious use of persuasion-coercion levels appropriate to the particular threat scenario to minimize conflict.

DuBois's proposition is that we need not go to war against someone whom we can persuade that collaboration as mutually preferable. Collaboration, DuBois explains, is dependent on our understanding of their culture, language, values and needs, which when mated with some creativity is more often productive than not. So why start killing rather than first making best efforts at collaboration? Strategically speaking, such a versatile, creative blend of persuasion and credible raw power (kinetic force) substantially furthers containment and reduces the probability of an Armageddon. Recalling Neville Chamberlain and the Munich affair in 1938, without a credible kinetic force, DuBois posits that gentle collaborative power has limited efficacy. So our author undertakes to present several methods for implementing his approach.

At whatever point a nascent conflict situation is entered, DuBois envisions a useful tool many American children have learned on the playground: a "Time-Out," or as the author calls it, a "Cause for Pause." Effectively invoking Viktor Frankl and Stephen Covey, DuBois reminds us that between every stimulus and response there is an opportunity for us to decide our best response. With the right approach, such opportunity can be used to ameliorate the situation and direct it toward an accord. Consis- 
tent with Andrew Krepinevich, the author gives some persuasive examples that such conflict management tools can be as effective internationally as interpersonally, for recouping objectivity and formulating mutually preferable if not collaborative solutions that preempt a conflict escalation into conventional warfare or worse.

Yet as the author cautions, human nature is flawed, emotions often overrule logic and the resort to armed conflict isn't necessarily allayed by respect, understanding and kindness alone. Sometimes, according to DuBois's Applied Smart Power thesis, war is the only alternative and particularly where survival is actually or merely perceived to be at stake. Having a kinetic (i.e., credibly ready, willing and able) force to apply to the scenario while exercising judicious restraint, is still the price for peace as the author's career achievements so well demonstrate.

In DuBois's way of thinking, improved understanding of whoever the "other" party may be is what makes conflict prevention almost certain, except in the event of necessary preemptive force. Hence, whenever we find ourselves at the use-of-force point on the Applied Smart Power continuum, DuBois finds kinetic force essential for credibility and preferred resolution. DuBois's message is patently clear. Collaboration-to-Combat gradient is the tool proposed for America's learning and mastering the lessons of Balanced Peacemaking.

While it may not be the simplest concept to implement, it is a creative and well stated perspective from a highly authoritative and welcome source. Striking vigorously at the roots of war, Powerful Peace illustrates how convenient resort to Total War (especially in Counter Insurgency scenarios) indiscriminately destroys not only life's essentials but no less effectively alienates much of the very support we seek and need to win. It shows the mistake of recourse to gratuitous slaughter like Arc Light, Agent Orange, or the annihilation realities of nuclear devastation.

In his ardor to curtail gratuitously destructive force in an age of Total War, DuBois may somewhat exaggerate the efficacy of human kindness but he makes the indelible point that it is only with and through the individual and collective efforts of mankind that peace is made. The alternative to less-than-best efforts in moderation in this nuclear age remains unthinkable.

Powerful Peace is definitely a book worth reading. While the book is superbly written and credibly supports its thesis, the impact of his fine examples would heighten with brevity. While DuBois's thesis is well supported, the arguments suffer for lack of balance by comparative or con- 
Journal of Strategic Security

trasting theses. If there is any criticism of the book, it may be that its goal is to stimulate dialogue rather than perfect pragmatic methods for implementing the thesis in policy and operations. But this book is just a first step for Robert DuBois. All in all, Powerful Peace is really a good read and well worth the price.

Don Sine, American Military University 